\title{
THE SOCIAL CONSEQUENCES OF VOICE: AN EXAMINATION OF VOICE TYPE AND GENDER ON STATUS AND SUBSEQUENT LEADER EMERGENCE
}

\author{
ELIZABETH J. MCCLEAN \\ University of Arizona \\ SEAN R. MARTIN \\ University of Virginia \\ KYLE J. EMICH \\ University of Delaware \\ COL. TODD WOODRUFF \\ United States Military Academy at West Point
}

\begin{abstract}
This paper explores the impact of two types of voice and gender on peer-rated social status and subsequent leader emergence. Across two studies-a three-wave field study and an experiment-we find that speaking up promotively, but not prohibitively, is positively and indirectly related to leader emergence via status, and that this relationship is conditional on the gender of the speaker. Specifically, men who spoke up promotively benefited the most in terms of status and leader emergence, not only compared to men who spoke up prohibitively, but also compared to women who spoke up promotively. This research extends our understanding of the outcomes of voice by articulating how it impacts one's place in his or her group's social structure, and ultimately whether he or she is seen as a leader. We also add to our understanding of leader emergence by suggesting that talking a lot or participating at a high level in a group may not be enough to emerge as a leader-it also depends how you do it and who you are.
\end{abstract}

Employee voice is a change-oriented behavior involving the discretionary provision of improvementoriented information intended to better one's group or organization (Detert \& Burris, 2007). Scholarly interest and research on the consequences of voice have largely developed along two paths; the first has examined the impact of voice on collective outcomes such as unit-level performance (Detert, Burris, Harrison, \& Martin, 2013) or turnover (McClean, Burris, \& Detert, 2013), and the second has examined the impact of voice on manager reactions including performance evaluations or endorsements (Burris, 2012; Howell, Harrison, Burris, \& Detert, 2015;

The authors would like to thank Amy Colbert and three anonymous reviewers for their conscientious and developmental feedback. We also thank Jean Bartunek, Ethan Burris, Jim Detert, Taeya Howell, and Nathan Podsakoff for early reviews of the manuscript. Last but not least, we would like to thank the men and women of the United States Army for taking the time to answer our survey request.
Whiting, Maynes, Podsakoff, \& Podsakoff, 2012). While studies have largely found that employee voice has a positive relationship with collective outcomes, studies exploring managerial reactions to voice have suggested that managers do not always respond positively to those who speak up (Burris, 2012; Howell et al., 2015). Conspicuously absent from this work, however, is an exploration of how peers or fellow team members perceive the speaker.

This omission is consequential. Theoretically, when choosing to speak up or remain silent, people engage in an expectancy-like "voice calculus," where they weigh the expected success and benefits of speaking up against the risks (Detert \& Burris, 2007; Milliken, Morrison, \& Hewlin, 2003). Since voice frequently targets managers, their potential reactions are naturally considered (Burris, 2012; Detert \& Edmondson, 2011). Employees are also likely to consider the social consequences of voice and incorporate potential peer reactions into their decision to speak up (Milliken et al., 2003), particularly if they work in a team or group setting where 
voice may affect the collective (Detert et al., 2013). However, prior work has yet to deeply explore the social consequences of voice (Milliken et al., 2003; Morrison, 2014) and so it remains unclear how peers actually evaluate those who speak up.

Further, much of the work that has alluded to the social consequences of speaking up among one's peers has focused on the potential costs of doing so (e.g., Kish-Gephart, Detert, Treviño, \& Edmondson, 2009; Morrison, 2014), and it is true that peers could respond negatively to voice; they might punish those who speak up because change initiatives could be seen as increasing their workload (Cartwright \& Cooper, 1993), as stirring fear and anxiety (Armstrong-Stassen, 1998; Ashford, 1988), or as unsolicited interference (Tepper, Duffy, Hoobler, \& Ensley, 2004). However, there are theoretical reasons to expect that peers will positively evaluate those who speak up. First, the purpose of voice is to benefit the collective (McClean et al., 2013), and while changes to the status quo may threaten some managers (Burris, 2012), they are less likely to threaten peers because the intent is to improve things for them. Second, voice is a change-oriented behavior, which is considered key to leadership (DeRue, Nahrgang, Wellman, \& Humphrey, 2011). Thus, those who engage in it may be seen as more leaderlike within a group. Finally, research from several areas has found that those who actively participate in groups can acquire elevated social positions (e.g., Bass, 1954; Fişek, Berger, \& Norman, 1991) because they are seen as more competent and socially skilled (Kennedy, Anderson, \& Moore, 2013).

In the present research, we explore the potential benefits of voice and argue that speaking up in a group relates to having elevated status, which subsequently affects emerging as a leader. However, we expect that these relationships are influenced by characteristics of the speaker and how they speak up. We address the question of how peers respond to voice by drawing upon expectation states theory (EST) (Berger, Conner, \& Fişek, 1974; Correll \& Ridgeway, 2003) as it provides a framework for understanding how group members interpret the behaviors of their peers and how those interpretations relate to a group's social order.

EST suggests that status is ascribed to others based on the different behaviors in which they engage (Fişek et al., 1991), and their socially significant characteristics (Berger et al., 1974; Correll \& Ridgeway, 2003). Regarding the types of behaviors that accrue status, EST posits that assertive behaviors result in status when they are accepted and valued by others (Fişek et al., 1991). There are various ways to speak up, and some ways may be seen as more or less acceptable, and thus differentially influence the extent to which peers ascribe status. We explore how engagement in promotive voice versus prohibitive voice-that is, voice expressing improvementoriented ideas for change versus concerns about potentially harmful work practices (Liang, Farh, \& Farh, 2012)—affects a speaker's status and subsequent leader emergence. While several classifications of voice have been proposed (e.g., Burris, 2012; Whiting et al., 2012), the promotive-prohibitive distinction has been widely established and most parsimoniously captures how people speak up. Concerning the characteristics that influence how behaviors are interpreted, EST argues that people with socially significant characteristics come to accrue greater status for the same behavior than those without those significant characteristics, suggesting that not everyone who engages in voice behaviors will be evaluated the same way. Following prior research in EST (see Ridgeway, 2001 for review), we focus on gender because it is one of the most culturally significant characteristics used to categorize people, particularly as it concerns perceptions of leadership (Eagly \& Karau, 1991). Finally, research in EST and leader emergence has jointly suggested that those who participate assertively in groups come to attain higher social positions of various types. Considering leader emergence in the context of EST suggests that one reason people emerge as leaders is because their assertive behaviors help them claim status and lead others to defer to their influence.

This research makes several contributions to the voice literature. First, we advance theory on the outcomes of voice by assessing how it affects one's social standing within a group. In doing so, we identify an unexplored individual-level benefit of voice- that those who speak up in a group might accrue status and come to be seen as leaders. When individuals come together with the purpose of achieving a group goal, hierarchies naturally arise (Magee \& Galinsky, 2008), individuals compete for position, and perceptions of each other are critical determinants of who gets ahead (Pettit, Yong, \& Spataro, 2010). Thus, this work shows how voice relates to this process. Second, we contribute to both the voice and leader emergence literature by suggesting that not all voice is equal in this process. Concerning the voice literature, scholars have largely focused on the antecedents of promotive and prohibitive voice (Liang et al., 2012), but few have addressed outcomes thereof (Chamberlin, Newton, 
\& Lepine, 2016). We argue that promotive and prohibitive voice may differentially affect whether others grant the speaker status, and subsequently whether the speaker emerges as a leader. Regarding voice and its role in leader emergence, research evidence has suggested that being assertive and participating in groups is related to leader emergence (Bass, 1954; Ensari, Riggio, Christian, \& Carslaw, 2011; Foti \& Hauenstein, 2007; Mullen, Salas, \& Driskell, 1989; Smith \& Foti, 1998; Sorrentino \& Boutillier, 1975). By linking this research to the voice literature that distinguishes between types of voice, we suggest that what matters is not simply whether one speaks up, but how they do so. Finally, by incorporating EST into the study of voice, we contribute to the limited literature on speaker characteristics (Howell et al., 2015) and highlight the importance of gender as a socially significant characteristic that influences how peers respond to and reward (or not) those who speak up.

\section{THE SOCIAL CONSEQUENCES OF VOICE}

\section{Expectation States Theory}

EST addresses how status hierarchies emerge in situations where individuals are oriented toward a collective goal (Berger et al., 1974; Correll \& Ridgeway, 2003). Two primary perspectives in EST-the evaluation-expectation and status characteristics perspectives (Fişek et al., 1991)—are particularly useful for understanding how certain types of voice and speaker gender affect others' perceptions of social standing. The evaluation-expectations perspective focuses on how behavioral patterns relate to the status structure of a group. It posits that behaviors such as assertive participation are attempts to claim status. Because voice is assertive and change oriented, it represents a potential statusclaiming behavior (Anderson \& Kilduff, 2009a). However, not all assertive behavior, and therefore, we argue, not all kinds of voice, will lead to status. Instead, the status claim must also be accepted by others (Fişek et al., 1991). The more frequently studied status characteristics branch of EST focuses on why people with different socially significant characteristics frequently do not receive the same status for engaging in the same claiming behaviors (Correll \& Ridgeway, 2003). This perspective argues that people have socially significant characteristics that influence whether other people see their status claim as legitimate-that is, something a person with those characteristics should be doing (Correll \&
Ridgeway, 2003). To the extent that one's statusclaiming behaviors align with others' expectations, the behavior is seen as legitimate and status is granted. To the extent that the status-claiming behavior does not align with others' expectations, it is seen as less legitimate and does not correspond to being granted status. Together, the evaluationexpectation and status characteristics perspectives suggest that status hierarchies are influenced by both the status-claiming behaviors that different group members engage in, and how group members' socially significant characteristics influence the perceived legitimacy of those behaviors.

\section{Voice and Status}

Social status is "the extent to which an individual or group is respected or admired by others" (Magee \& Galinsky, 2008: 359), and is the outcome of a subjective conferral process (Blader \& Chen, 2014). Findings from the social psychology literature on status have largely confirmed the evaluationexpectations perspective, finding that individuals can accrue status through a variety of status-claiming behaviors, including doing things that signal competence, acting selflessly on behalf of the group, and otherwise enhancing the value they provide to others (Anderson \& Kilduff, 2009b; Correll \& Ridgeway, 2003; Fişek et al., 1991). Voice is a change-oriented, assertive, and risky behavior (Morrison, 2014), and has the potential to enhance one's status in a group because it signals competence, a communal orientation, and a willingness to assume risk on behalf of others. To speak up, individuals need to possess enough knowledge of the group, work process, or team environment to be able to suggest change. Prior research has also confirmed that individuals who speak up regularly are seen as more competent and confident, which relates to status attainment (Anderson \& Kilduff, 2009b; Hall, 1979; Kennedy et al., 2013; Riggio, 1986). Further, assuming risk for others and making suggestions to improve the collective can be interpreted by peers as reflecting an altruistic, communal orientation, which is positively related to status conferral (Hardy \& Van Vugt, 2006). Thus, we expect individuals who speak up to be conferred more status than those who do not.

However, not all assertive behaviors garner status equally (Fişek et al., 1991). Behaviors that are seen as more valuable are more likely to be accepted by others and have a higher likelihood of influencing one's status (Fişek et al., 1991). Within the voice literature, scholars have noted that there are different 
types of voice (Burris, 2012; Liang et al., 2012; Maynes \& Podsakoff, 2014) and these types may vary in the value they are seen to add and the degree to which they are accepted by others. Promotive voice refers to the "expression of new ideas or suggestions for improving the overall functioning of the work unit or organization" (Liang et al., 2012: 74). The impetus behind promotive voice is to move the collective toward an ideal state. It is inherently future oriented because it involves offering ideas about how to do things better in the future and suggesting ways to improve the organization. In contrast, prohibitive voice is the "expression of concern about work practices, incidents, or employee behaviors that are harmful to one's organization" (Liang et al., 2012: 75). The motivation behind prohibitive voice is to direct the collective away from a feared state. It can be either past or future oriented as it highlights existing or impending factors that should be stopped (Liang et al., 2012).

While both types of voice are potentially valuable to a group, we expect that promotive voice is likely to be perceived by others as more valuable and readily accepted than prohibitive voice, and thus should relate more strongly to status (Fişek et al., 1991). Concerning acceptability, Webster and Raschotte (2010) suggested that if group members feel that someone is influencing their group in the wrong way, they are likely to suppress that person and deny status. Conversely, if someone is influencing their group in an acceptable way, group members are likely to grant status. Promotive voice, with its focus on moving toward ideal states, is associated with a promotion focus or an approach motivation (Lin \& Johnson, 2015). Promotive behaviors focus people's energy and attention on ideal states, and thinking about ideal states activates positive emotions such as enthusiasm and excitement (Kark \& Van Dijk, 2007). More broadly, studies have found that an approach orientation can activate optimism, motivation, and positive affect (Lanaj, Chang, \& Johnson, 2012). As such, promotive voice, being associated with an approach orientation and engendering positive affect, is negatively related to a speaker's ego depletion or the consumption of self-regulatory resources (Lin \& Johnson, 2015). The positive states one experiences and vocalizes when promoting ideas are likely to spread to other group members (Barsade, 2002), making them vicariously experience more positive affect and thus also sustaining their self-regulatory resources (Barsade, 2002; Lin \& Johnson, 2015).

Alternatively, prohibitive voice, with its focus on identifying problems and moving away from negative or feared states, is associated with a prevention focus or avoidance motivation (Lin \& Johnson, 2015). While useful in preserving safety and security by making people more alert to threats and fears, this orientation can trigger negative emotions and deplete one's regulatory resources by making them vigilant of potential problems in their environment (Crowe \& Higgins, 1997; Lanaj et al., 2012; Liang et al., 2012; Lin \& Johnson, 2015). When broadcast, negative emotions can easily spread to others so that they too experience negative affect and the depletion of regulatory resources (Barsade, 2002; de Gelder, Snyder, Greve, Gerard, \& Hadjikhani, 2004).

Thus, while both types of voice are potentially status-claiming behaviors, and while both can add value, considering them as reflective of approach or avoidance orientations suggests that speaking up promotively or prohibitively may differentially influence team members and relate to the status one is granted for providing voice (Fişek et al., 1991). Promotive voice adds value while engendering positive affect and conserving members' self-control resources, and therefore should be more likely seen as influencing a group in the "right" way. Prohibitive voice may add value, but can also trigger negative affect and the depletion of self-regulatory resources. This is consequential because individuals who stir negative emotions may not be conferred status to the same degree as those who engender positive emotions (Lovaglia \& Houser, 1996; Tiedens, 2001). These arguments align with other social-psychological research concerning status, which has found that people who are more approach oriented tend to be allocated more status than people who are avoidance oriented (Kilduff \& Galinsky, 2013). This leads us to expect:

Hypothesis 1a. Promotive voice is positively related to status.

Hypothesis 1b. Prohibitive voice is positively related to status.

Hypothesis 1c. The positive relationship between promotive voice and status is stronger than the positive relationship between prohibitive voice and status.

\section{Voice, Status, and Leader Emergence}

Leader emergence reflects the extent to which one is seen as leader-like (Kaiser, Hogan, \& Craig, 2008). It results from social interaction and reflects collective perceptions by members that a person "could serve 
the group more usefully in attaining group goals than the other members" (Bass, 1981: 13). Distinct from leader effectiveness, which assesses perceived approval of one's performance, emergence assesses whether a person stands out within a group in terms of the influence he or she wields (Kaiser et al., 2008). Akin to the evaluation-expectations perspective in EST (Fişek et al., 1991), DeRue and Ashford (2010) argued that people come to be seen as leaders by engaging in behaviors that claim leadership, or assert influence over others. Verbal assertions are argued to be a key type of leadership-claiming behavior (DeRue \& Ashford, 2010), and research has supported the premise that those who speak more in groups tend to emerge as leaders (Bass, 1954; Mullen et al., 1989; Sorrentino \& Boutillier, 1975; Sorrentino \& Field, 1986). However, leader emergence also depends upon whether others grant leadership, or accept a group member's claiming behavior and allow themselves to be influenced (DeRue \& Ashford, 2010; Fişek et al., 1991; Taggar, Hackew, \& Saha, 1999).

We expect that status relates to being seen as leader-like and being awarded influence by other group members. Status scholars have argued that the ability to exert influence in a group is a downstream consequence of one's respect within a group (Blader \& Chen, 2014; Fiske \& Berdahl, 2007; Magee \& Galinsky, 2008). People define themselves in terms of the groups they belong to (Tajfel \& Turner, 1979), and look to highly respected others to fill positions of leadership because individuals are inclined to choose leaders who will positively affect their sense of self (Ellemers, De Gilder, \& Haslam, 2004). Team members will benefit from choosing someone who is respected as their leader because high-status leaders are better able to garner resources, gain the trust of key stakeholders, and ensure the survival of the team itself (Cialdini, Borden, Thorne, Walker, Freeman, \& Sloan, 1976; Graffin, Wade, Porac, \& McNamee, 2008). Thus, team members stand to benefit to the extent to which their leader is highly respected.

We argue that voice will relate to having higher status in a group, to the extent that it is seen as adding value and is accepted by team members, and that those with higher status will be better able to influence others and compel deference to their suggestions because individuals will want to align themselves with the high-status team members. Thus, our prior theoretical arguments posit that promotive and prohibitive voice positively relate to one's status in a group, and here we argue that one's status position in a group is related to leader emergence. Together, these arguments suggest that voice affects leader emergence through its effect on perceived social status. We therefore predict that:

Hypothesis 2. Status mediates the relationship between promotive voice and leader emergence.

Hypothesis 3. Status mediates the relationship between prohibitive voice and leader emergence.

\section{The Moderating Role of Gender}

According to the status characteristics branch of EST, the status attributed to a group member as a result of his or her behavior depends not only on the behaviors themselves, but also on others' perceptions of his or her socially significant characteristics (Berger, Cohen, \& Zelditch, 1972). Gender is one of the most basic and culturally meaningful characteristics used to categorize individuals, particularly when gender is culturally linked to the task (i.e., leadership) (Ayman \& Korabik, 2010), and prior research has shown that it influences others' perceptions of value and status within groups (Ridgeway, 2001). When gender is salient, gendered beliefs about appropriate actions shape the interpretation and perceived acceptability of behaviors (Ridgeway, 2001). Beliefs about how men and women should behave are widely held; men are thought to be more agentic and competent, whereas women are thought to be more reactive and communal (Fiske, 1998). Because of this implicit assumption about competence and agency, men's assertive behaviors are often seen as more legitimate and as adding more value to the group than are women's similar behaviors. As such, men tend to be the more status-advantaged group members (Eagly \& Wood, 1982), and research has affirmed that men are often conferred more status than are females across an array of contexts (Eagly \& Wood, 1982; Fiske, Cuddy, Glick, \& Xu, 2002).

Consistent with this work, we expect that group members will evaluate men who speak up as acting more legitimately compared to women who do so because assertive, change-oriented behaviors are more in line with gendered expectations for men (Ridgeway, Backor, Li, Tinkler, \& Erickson, 2009). We expect this to be true regardless of whether men speak up promotively or prohibitively because both are change-oriented assertive behaviors, which are more aligned with the cultural expectations of men compared to women (Ridgeway, 2001). Thus, combined with our prior arguments, we expect that the relationships between promotive and prohibitive voice, and leader emergence via status, will be 
conditional on gender, such that the effects are stronger for men than for women.

Hypothesis 4. Gender moderates the indirect effect of promotive voice on leader emergence via status, such that the relationship is stronger for men than for women.

Hypothesis 5. Gender moderates the indirect effect of prohibitive voice on leader emergence via status, such that the relationship is stronger for men than for women.

\section{OVERVIEW OF STUDIES}

We designed two studies to test our proposed conditional process model, as presented in Figure 1. Study 1 is a lagged survey design in a field setting using a sample of real teams interacting frequently over the course of several months, and engaged in behaviors and decisions that have meaningful consequences, thus providing an ecologically valid test of our hypotheses. Study 2 uses a between-subjects randomized experimental vignette design in which participants evaluate the voice of a person, with whom they have no realworld experience, about a specific instance at one point in time. This design provides evidence of causality, and helps address several of the limitations of our field study by holding constant the content and quantity of voice, assessing its effects in one discrete moment, removing the effects of having any prior acquaintance with the speaker, and exploring our hypotheses with a different population and context.

\section{STUDY 1}

\section{Setting}

In Study 1, we test our hypotheses in a field setting involving all 36 United States Military Academy (USMA) teams competing in the annual Sandhurst competition held at the United States Military Academy at West Point. The Sandhurst competition is a two-day military skills competition. Teams train for roughly four months to prepare for the competition. The competition itself involves teams traversing a nearly six-mile course filled with numerous obstacles that test different mental and physical abilities, and culminates with a large award ceremony in which successful teams are recognized and rewarded in front of their fellow soldiers. USMA teams are formed from companies-collections of cadets that live and participate in formal activities together both before and after the competition. Teams are required to have at least one woman and to include participants from all USMA class levels. This setting provides a good opportunity to test our hypotheses because individuals interact frequently for an extended period of time in pursuit of a salient and desirable collective outcome.

\section{Participants and Procedure}

We sent surveys to Sandhurst participants at three time points-three months prior to the competition, when group training had commenced (Time 1); 10 days before the competition, when training was coming to a close (Time 2); and immediately following the competition (Time 3 ). There were 36 teams

FIGURE 1

Voice Type, Gender, Status, and Leader Emergence

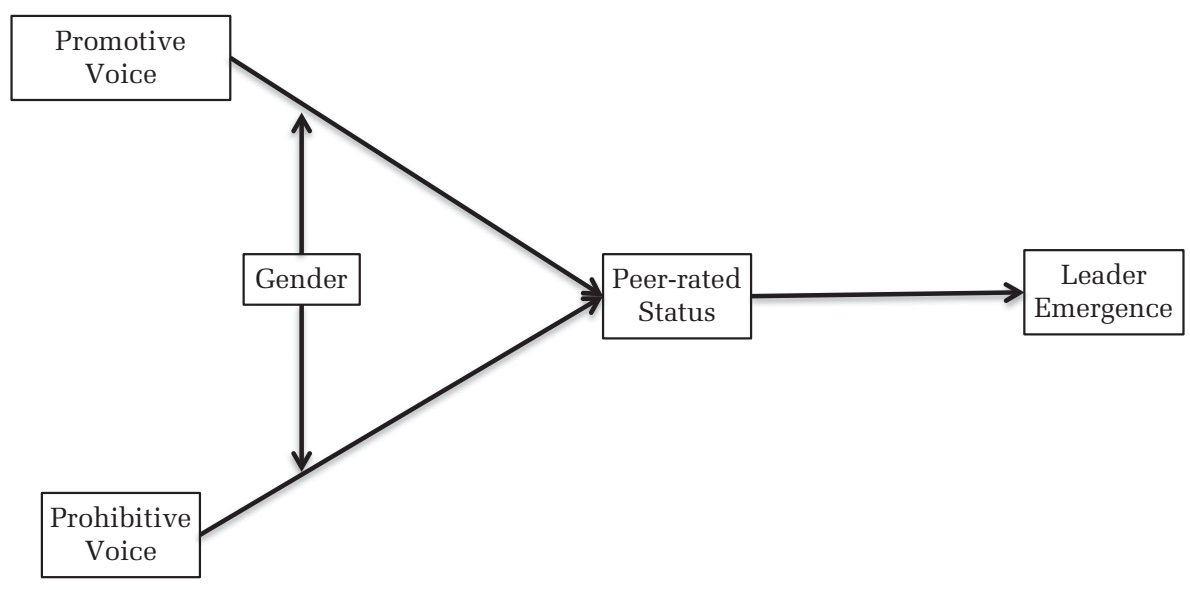


in the competition. Each team has 10 competitors, including one formal leader who is the equivalent of a college senior who will graduate from USMA at the end of the year and is not be eligible to lead the team in future events. The formal leader was excluded from analysis. Each team had between one and three women, with an average of two. A total of 174 of of the eligible 324 competing USMA cadets (54\%) completed all three surveys.

\section{Measures}

Promotive and prohibitive voice. To measure the two types of voice, we asked each individual to rate the frequency with which they spoke up promotively and prohibitively using three ${ }^{1}$ items each from Liang et al. (2012) at Time 1. An example item for promotive voice is, "I proactively develop and make suggestions for issues that may influence my team," and an example item for prohibitive voice is, "I advise other teammates against undesirable behaviors that would hamper job performance." Each item was rated on a scale of 1 (almost never) to 5 (almost always). Each set of items showed good reliability.

Gender. Information on gender was provided by the USMA. Male participants are coded as 0 and female participants as 1 .

Status. To measure status, we adapted items from Anderson, Kraus, Galinsky, and Keltner (2012). Specifically, we used a round-robin approach at Time 2, where each team member rated each other's status level using two items: "This person has a high level of respect in others' eyes" and "This person is held in high regard by others." Each item was rated on a scale of 1 (disagree) to 5 (agree). These items showed good reliability. Each participant was rated by an average of 6.61 peers, and their ratings were aggregated. Intraclass correlation coefficients (ICCs) indicate significant agreement among team members

\footnotetext{
${ }^{1}$ For each type of voice there was one item that did not apply to our setting, and one item that we perceived as being redundant compared to the others in this setting. We therefore removed these items from our survey, resulting in three items per voice-type rather than the five items used by Liang et al. (2012). To ensure our scales accurately represented each construct we ran a validation study with a panel of 284 Master MTurk workers. Our analyses indicated that a two-factor solution fit the three-item measures well, and the three-item measures of promotive and prohibitive voice correlated with the five-item measures at $r=.98$ and $r=.97$, respectively. Validation measures available upon request.
}

$(\mathrm{ICC} 1=.39, \mathrm{ICC} 2=.83, F(170,1151)=5.93, p<.00$, median $\mathrm{r}_{\mathrm{wg}}=.87$ ).

Leader emergence. Leader emergence was measured at Time 3 (post-competition). We followed Smith and Foti's (1998) procedure to measure leader emergence by listing all team members' names and asking each member the following question: "If you had the opportunity to work with this exact same group of people again, and were asked to prepare for and compete with them in the Sandhurst Competition again, please rank in order your preference for who you would want to be the team leader by clicking and dragging the people below into the positions you believe they should be in." To calculate leader emergence, we averaged teammates' ranking of each team member. Lower ranks indicated a greater preference for a given teammate to lead in the future (e.g., a "1" indicated a respondent's top choice to be their future leader). Our measure does not include rankings from the formal leader on the team, only other peer members. Each participant was ranked by an average of 5.52 peers.

We chose this measure of leader emergence because it is consistent with prior work, and the context of our study is formal teams whose leaders will be replaced the following year. In this case, a rank measure reduces rater effects (see Zaccaro, Foti, \& Kenny, 1991) and provides clearer information about who team members see as having emerged more than others, and therefore as being more capable to assume the formal leadership position in the future. In formal groups, leaders who emerge are often those who consistently have or are seen as having the most influence over others (see Taggar et al., 1999), and two people cannot simultaneously hold the position of formal leader. A rating measure risks obscuring the determination of which team members more consistently exert greater influence over others such that they are seen as worthy of the formal role, because it introduces the possibility of multiple team members having the same score. While this may be a strength in informal team settings where no single person needs to emerge in a consistent way over time and multiple people can share leadership functions, in our formal team context we believe it is important to know who people saw as emerging to the greatest and most consistent extent.

To assess rater agreement, we followed recommendations for ranking-type data by Burke and Dunlap (2002) to calculate median average deviation $\left(A D_{\text {med }}\right)$, and compare our results against a uniform distribution, which is the distribution that would result if every ranking were given by chance. 
This procedure suggests a maximum value of 2.75 , and the $A D_{\text {med }}$ in our sample was 1.33 - significantly below the suggested cutoff-while only $5 \%$ of participants had $A D_{\text {med }}$ above the suggested cutoff. These results suggest significant ranking agreement among team members.

Control variables. We controlled for several alternative explanations for leader emergence following the guidelines of Carlson and Wu (2011). First, given that the context of this study is an athletic contest and athletic competence may affect who speaks up and is viewed as a leader, we controlled for athletic ability using a measure provided by the USMA. This value ranged between 100 and 800, with 800 indicating a higher athletic ability. Second, we controlled for participants' cognitive ability because prior research (Taggar et al., 1999) has suggested that it plays a meaningful role in leader emergence. To do so, we included their SAT (Scholastic Aptitude Test) score using archival information provided by USMA from participants' application materials. Third, because personality is a strong predictor of leadership (DeRue et al., 2011), we controlled for proactive personality, as well as the Big 5 personality traits. We used four items from Crant (1995) and validated by Detert and Burris (2007) to measure proactive personality. Example items include, "When I see a problem, I tackle it head on," and "I am always looking for better ways to do things." To control for the Big 5 traits we used the Ten Item Personality Inventory (TIPI) (Gosling, Rentfrow, \& Swann, 2003) at Time 1. We also controlled for psychological safety, measured at Time 2, using the seven items from Edmondson (1999), since perceptions of safety may confound our results because it positively and significantly relates to both voice and status (Edmondson, 2003). An example item is, "It is safe to take a risk on this team."

\section{Results}

Correlations and descriptive statistics are presented in Table 1. Cronbach's $\alpha$ reliability for each scale appears along the diagonal. All independent variables showed strong reliability.

We first conducted confirmatory factor analyses (CFAs) on all study variables except the single-item observed variables (athletic and cognitive ability) and the ranking measure of leader emergence because rank measures do not allow interitem correlations. Hu and Bentler (1999) recommended a combination of a standardized root mean residual (SRMR) $<.09$ and comparative fit index (CFI) close to .95 to determine good model fit. The nine-factor model was a marginal fit of the data $\left(\chi^{2}[305]=622.95\right.$; SRMR $=.09$; CFI $=$ .83). The factor loadings indicated that the compromised fit was due to the TIPI Big 5 measures, which are known to perform poorly in CFAs (Gosling et al., 2003). Removing the TIPI measures produced a fourfactor model that was an acceptable fit of the data $\left(\chi^{2}[125]=252.91 ;\right.$ SRMR $=.07$; CFI $\left.=.91\right)$, and a better fit than an alternative model in which the two types of voice were collapsed onto a single latent factor $\left(\chi^{2}[129]=262.72\right.$; SRMR $=.07$; CFI $=.90$; $\chi_{\text {diff }}^{2}[4]=9.81, p=.04$ ), suggesting that the two types of voice are better treated as separate constructs.

We tested for potential nonindependence of responses using multilevel analyses and found no significant between-group variance in leader emergence, meaning that team-level variance does not explain a significant portion of variance in leader emergence rank. We therefore do not nest our data for subsequent analyses.

Table 2 presents the results of our regressions testing the relationships between voice, status, and leader emergence. Given that our two types of voice were highly correlated, to test Hypotheses $1 \mathrm{a}$ and $1 \mathrm{~b}$, that promotive and prohibitive voice, respectively, are positively related to status, we ran separate models including promotive (Model 1) and prohibitive (Model 2) voice independently, then included them together (Model 3). Promotive voice was significantly related to status (Model 1: $\beta=.17$ (.06), $p<.01$ ), while prohibitive voice was marginally significant (Model 2: $\beta=.10$ (.05), $p=0.07$ ) when entered independently, but only promotive voice remained significant when both types of voice were entered together (Model 3: $\beta=.20(.08), p=$ .02). Thus, we conclude that Hypothesis 1a is supported, but Hypothesis $1 \mathrm{~b}$ is not.

To test Hypothesis 1c, regarding the relative importance of promotive and prohibitive voice as they relate to status, we conducted a relative importance analysis (Tonidandel \& LeBreton, 2011). This procedure employs bootstrap regression to generate a partitioned $R^{2}$ statistic called "lmg" for each model variable. It then generates bootstrapped confidence intervals around the difference between the two lmg values of interest, thus providing a means to assess whether the difference in relative importance between two variables is significant. This method produced lmg values of .05 and .02 for promotive and prohibitive voice, respectively, and the two variables account for approximately $7 \%$ of the variance in the model. The $95 \%$ confidence interval around the difference in effect size excludes zero (difference $=.03$ [.0002, .08]). Thus, we conclude that Hypothesis 1c is supported, 


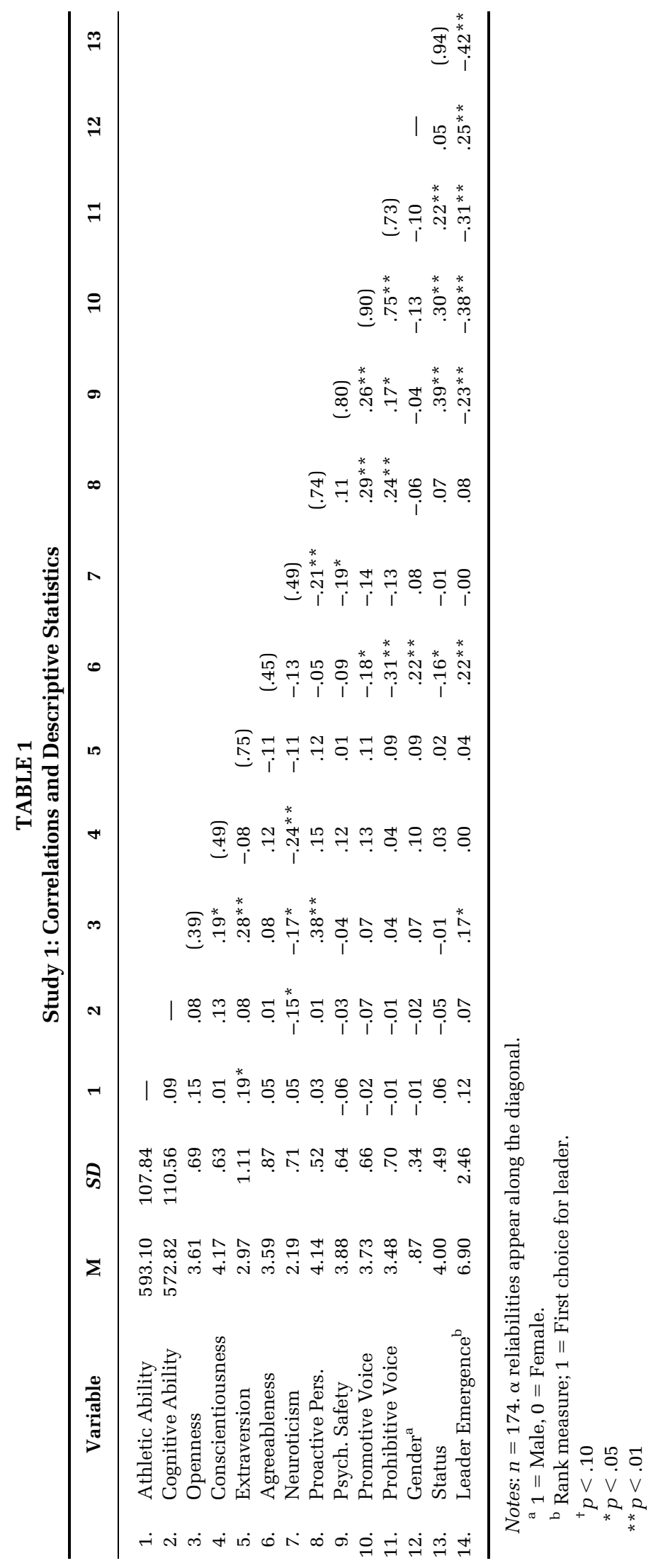


TABLE 2

Study 1: Voice Types, Status, and Leader Emergence

\begin{tabular}{|c|c|c|c|c|c|c|c|c|}
\hline & \multicolumn{6}{|c|}{$D V=$ Status } & \multicolumn{2}{|c|}{$\frac{D V=\text { Leader Emergence }}{\text { Model } 4}$} \\
\hline & B & $S E$ & B & $S E$ & B & $S E$ & B & $S E$ \\
\hline Intercept & $2.29 * *$ & 0.56 & $2.36^{* *}$ & 0.58 & 2.33 & 0.57 & $10.40^{* *}$ & 2.71 \\
\hline \multicolumn{9}{|l|}{ Controls } \\
\hline Athletic Ability & 0.43 & 0.00 & 0.41 & 0.00 & 0.44 & 0.33 & $0.002^{+}$ & 0.001 \\
\hline Conscientiousness & -0.03 & 0.06 & -0.01 & 0.06 & -0.03 & 0.06 & -0.13 & 0.27 \\
\hline Extraversion & -0.02 & 0.03 & -0.02 & 0.03 & -0.03 & 0.03 & -0.02 & 0.15 \\
\hline Agreeableness & -0.07 & 0.04 & -0.06 & 0.04 & $-0.07^{+}$ & 0.04 & 0.12 & 0.20 \\
\hline Neuroticism & 0.03 & 0.05 & 0.03 & 0.05 & 0.03 & 0.05 & -0.08 & 0.24 \\
\hline Proactive Personality & -0.01 & 0.08 & 0.01 & 0.08 & -0.01 & 0.07 & $0.81^{*}$ & 0.34 \\
\hline Psychological Safety & $0.26^{* *}$ & 0.06 & $0.29^{* *}$ & 0.06 & $0.26^{* *}$ & 0.06 & -0.07 & 0.28 \\
\hline \multicolumn{9}{|l|}{ Mediator } \\
\hline Status & & & & & & & $-1.79 * *$ & 0.36 \\
\hline$F$ & $4.40^{* *}$ & & $3.78^{* *}$ & & $4.03^{* *}$ & & $7.25^{* *}$ & \\
\hline$R^{2}$ & 0.23 & & 0.20 & & 0.23 & & 0.37 & \\
\hline Adj. $R^{2}$ & 0.18 & & 0.15 & & 0.17 & & 0.32 & \\
\hline
\end{tabular}

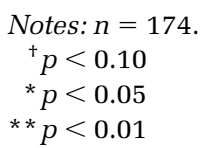

suggesting that promotive voice is more strongly related to status than is prohibitive voice.

To test our mediation hypotheses (Hypothesis 2 and Hypothesis 3), we used a bootstrap mediation method with 1,000 samples with replacement and percentile bootstrap confidence intervals. Model 4 in Table 2 shows the regression of the voice variables and status on leader emergence. The results of each indirect, direct, and total effect with corresponding confidence intervals are presented in Table 3. Supporting Hypothesis 2, the indirect effect of promotive voice on leader emergence through status was significant (effect $=-.29 ; 95 \% \mathrm{CI}:-.61,-.03$ ), as indicated by the confidence interval excluding zero. The direct effect from promotive voice to leader emergence was also significant (effect $=-1.05 ; 95 \%$ CI: $-1.82,-.24)$, indicating complementary mediation and suggesting that there are other, unmeasured pathways by which promotive voice may relate to leader emergence (Zhao, Lynch, \& Chen, 2010). The confidence interval around the indirect effect of prohibitive voice on leader emergence via status included zero (effect $=.04 ; 95 \%$ CI: $-.25, .32$ ); thus, Hypothesis 3 is not supported.

To test Hypotheses 4 and 5, concerning the conditional effect of gender on the indirect effect of each voice type on leader emergence, we performed a moderated mediation analysis. The regression models for these analyses appear in Table 4 . We first included gender as a moderator by introducing an interaction term between gender and each type of voice to predict status. As before, given the multicollinearity between the two voice types, we included each interaction separately (Models 1 and 2) before including them jointly (Model 3). The interaction between gender and promotive voice is significantly related to status when considered independently (Model 1: $\beta=-.31$ (.14), $p=.02$ ) and when entered jointly with the interaction of prohibitive voice and gender (Model 3: $\beta=-.41$ (.21), $p=.055$ ). We plotted the interaction using parameter estimates of status for both men and women (see Figure 2) and found that the shape of the interaction was as predicted. The simple slopes for the impact of 
TABLE 3

Study 1: Summary of Indirect Effects and Conditional Indirect Effects

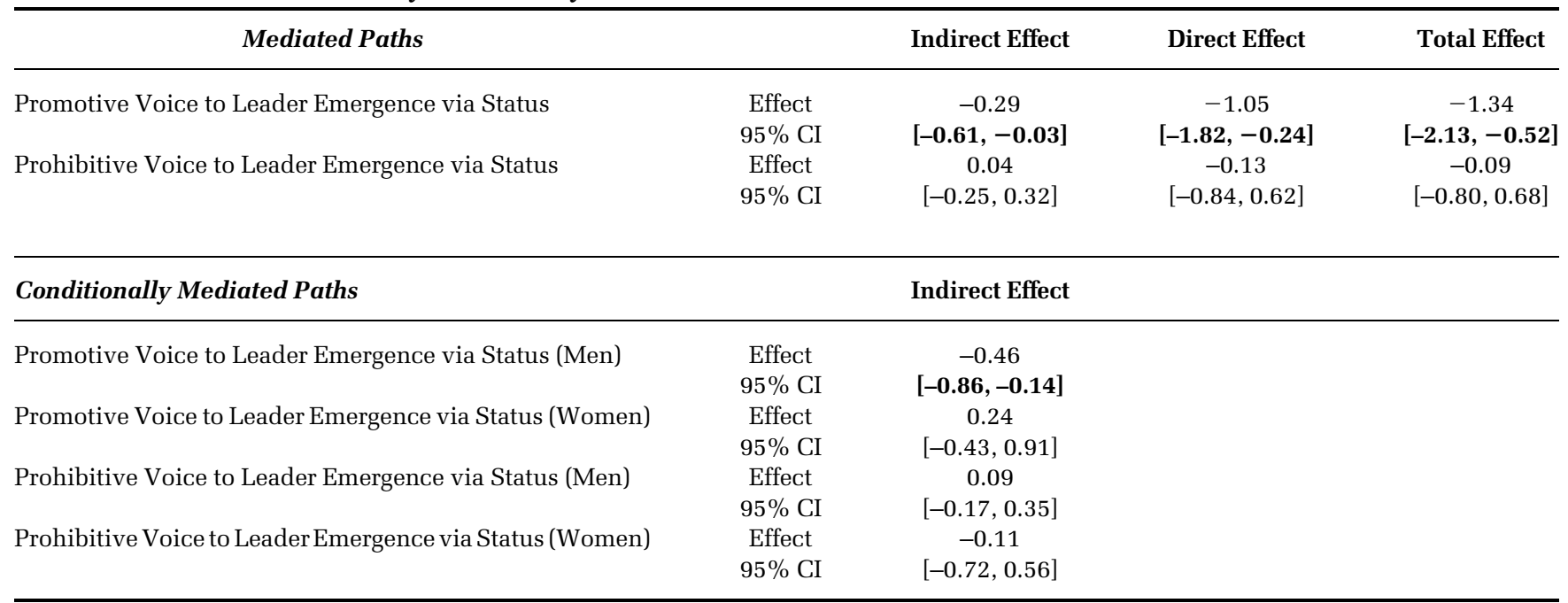

Notes: Bold indicates that confidence interval excludes zero. $n=174$.

promotive voice on status were significant for men ( $\beta=.47$ (.06), $p<0.01)$, but not for women $(\beta=$ -0.08 (.12), n.s.), indicating that men receive a benefit for speaking up promotively, but women do not. The interaction of prohibitive voice and gender is not significant. Model 4 shows that status is significantly related to leader emergence $(\beta=-1.70$ (.37), $p<$ .01). Using the bootstrap mediation procedure described above, we tested whether the mediated effect of voice on leader emergence via status was conditional upon the gender of the speaker. Supporting Hypothesis 4, Table 3 shows that the indirect effect of promotive voice on leader emergence via status is significant for men (effect $=-.46 ; 95 \% \mathrm{CI}:-.86,-.14$ ), but not for women (effect $=.24 ; 95 \% \mathrm{CI}=-.43, .91$ ). Following Edwards and Lambert (2007), we further explored the significance of the difference between the indirect effects of promotive voice on leader emergence for men and women, and found that it was significantly different at the $90 \%$ confidence level (difference $=-.69 ; 90 \%$ CI $[-1.33,-.07]$ ), though not at the $95 \%$ confidence level (95\% CI $[-1.57, .09])$. The indirect effect of prohibitive voice on leader emergence through status was not significant for men or women. Hypothesis 5 is not supported.

In sum, our results indicate that the types of voice people provide and their gender significantly interact to influence their leader emergence through the accrual (or not) of status. In particular, promotive voice improved leader emergence via status more than prohibitive voice did, but only for men. Our findings indicate that women received no benefit from speaking up promotively in terms of status or leader emergence.

\section{STUDY 2}

We sought to replicate the findings from our field study in another context, and to address the possibility of reverse causality-that higher-status participants engaged in more voice. We therefore designed an experiment employing a scenario task and a very different sample.

\section{Design, Task, and Manipulations}

We used a $2 \times 2$ between-subjects design varying the gender of the speaker (male vs. female) and type of voice (promotive vs. prohibitive). A total of 196 adults across a variety of industries were recruited using Amazon Mechanical Turk (MTurk). The average participant age was 39 years old, and $87 \%$ were employed full time. Participants had an average of 15.6 years of full-time work experience, $55 \%$ had a four-year college degree, and 38\% were female.

\section{Scenario Task}

Participants were asked to imagine they were part of an insurance sales team at InsureCo, a national insurance company responsible for selling personal insurance plans. We chose the insurance industry because it is gender balanced; approximately half of those employed in insurance sales or related 
TABLE 4

Study 1: Voice-Gender Interactions, Status and Leader Emergence

\begin{tabular}{|c|c|c|c|c|c|c|c|c|}
\hline & \multicolumn{6}{|c|}{$D V=$ Status } & \multirow{2}{*}{\multicolumn{2}{|c|}{$\frac{D V=\text { Leader Emergence }}{\text { Model } 4}$}} \\
\hline & \multicolumn{2}{|c|}{ Model 1} & \multicolumn{2}{|c|}{ Model 2} & \multicolumn{2}{|c|}{ Model 3} & & \\
\hline & B & $S E$ & B & $S E$ & B & $S E$ & B & $S E$ \\
\hline Intercept & 0.99 & 0.81 & $1.64^{*}$ & 0.76 & 1.04 & 0.82 & $14.86 * *$ & 3.77 \\
\hline \multicolumn{9}{|l|}{ Controls } \\
\hline Athletic Ability & 0.05 & 0.03 & 0.05 & 0.03 & 0.05 & 0.03 & 0.00 & 0.00 \\
\hline Cognitive Ability & 0.00 & 0.03 & 0.00 & 0.03 & 0.00 & 0.03 & 0.00 & 0.00 \\
\hline Openness to Experience & 0.01 & 0.05 & 0.01 & 0.06 & 0.02 & 0.06 & 0.28 & 0.26 \\
\hline Conscientiousness & -0.03 & 0.06 & -0.03 & 0.06 & -0.04 & 0.06 & -0.12 & 0.27 \\
\hline Extraversion & -0.01 & 0.03 & -0.02 & 0.03 & -0.01 & 0.03 & -0.05 & 0.14 \\
\hline Agreeableness & $-0.08^{\dagger}$ & 0.04 & $-0.08^{+}$ & 0.04 & $-0.08^{+}$ & 0.04 & 0.14 & 0.20 \\
\hline Neuroticism & 0.03 & 0.05 & 0.03 & 0.05 & 0.03 & 0.05 & -0.11 & 0.24 \\
\hline Proactive Personality & -0.03 & 0.08 & -0.02 & 0.08 & -0.03 & 0.08 & $0.91 * *$ & 0.35 \\
\hline Psychological Safety & $0.26^{* *}$ & 0.06 & $0.26 * *$ & 0.06 & $0.26^{* *}$ & 0.06 & -0.06 & 0.27 \\
\hline \multicolumn{9}{|l|}{ Independent Variables } \\
\hline Promotive Voice & $0.57 * *$ & 0.18 & $0.20 *$ & 0.08 & $0.69 *$ & 0.27 & -1.60 & 1.24 \\
\hline Prohibitive Voice & -0.03 & 0.08 & 0.17 & 0.17 & -0.17 & 0.24 & -0.87 & 1.11 \\
\hline Gender & $1.30 * *$ & 0.50 & 0.66 & 0.43 & $1.25^{*}$ & 0.50 & -2.20 & 2.35 \\
\hline \multicolumn{9}{|l|}{ Mediator } \\
\hline Status & & & & & & & $-1.70^{* *}$ & 0.37 \\
\hline \multicolumn{9}{|l|}{ Interactions } \\
\hline Promotive $\times$ Gender & -0.31 * & 0.14 & & & $-0.41^{+}$ & 0.21 & 0.59 & 0.99 \\
\hline Prohibitive $\times$ Gender & & & -0.15 & 0.13 & 0.12 & 0.20 & 0.53 & 0.90 \\
\hline$F$ & $4.22 * *$ & & $3.88 * *$ & & $3.93 * *$ & & $6.52 * *$ & \\
\hline$R^{2}$ & 0.26 & & 0.24 & & 0.26 & & 0.38 & \\
\hline Adj. $R^{2}$ & 0.19 & & 0.18 & & 0.19 & & 0.32 & \\
\hline
\end{tabular}

Note: $n=174$.

${ }^{\dagger} p<0.10$

$* p<0.05$

$* * p<0.01$

activities are women according to the U.S. Bureau of Labor Statistics Current Population Survey in 2014.

We varied our scenarios according to two of the primary dimensions along which promotive and prohibitive voice are argued to differ-behavioral content and function (Liang et al., 2012). Behavioral content refers to whether one is expressing an idea for future improvement, as in the case of promotive

FIGURE 2

Study 1: Interaction Between Promotive Voice and Gender on Status

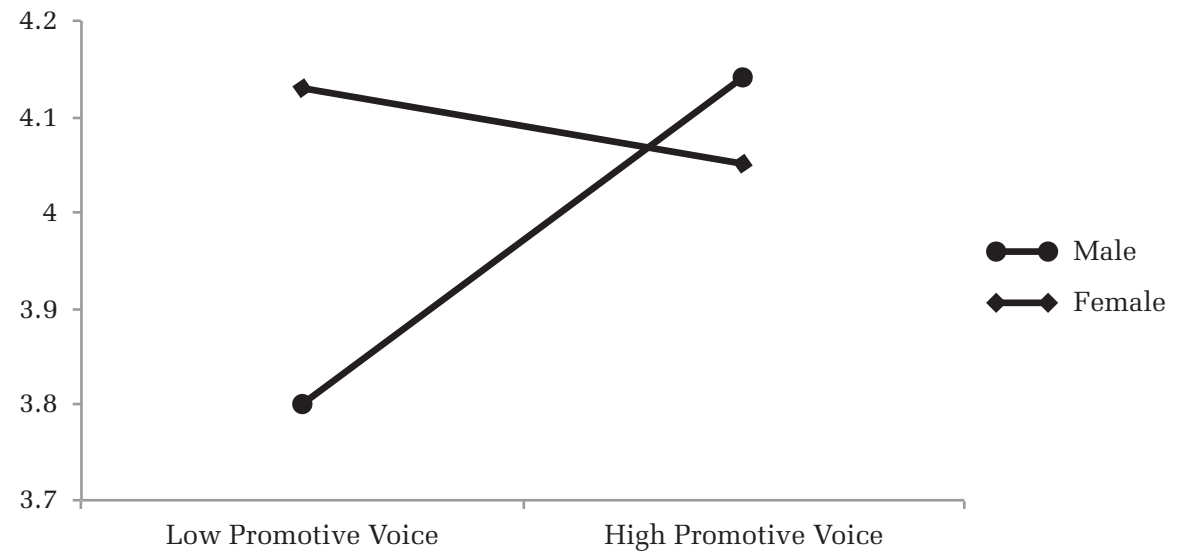


voice, or stopping a problem, as in the case of prohibitive voice. Function refers to the suggestion about what is to be done about the idea or problem. Promotive voice points out ways in which improvements can be made, whereas prohibitive voice points out practices or behaviors that should be stopped. We therefore manipulated the promotive condition to incorporate expressing an idea to improve the current situation (behavioral content) using a specific suggestion (function). In contrast, we created the prohibitive condition to incorporate identifying a problem with existing practices (behavioral content) and suggesting that it be stopped (function).

To sell insurance plans, team members typically use a company-provided script. In our scenario, participants were told that they had been working with their team members for about nine months and that three months ago, they started using a new script. Since the adoption of the new script, performance has suffered. In this month's team meeting, the manager gave a pep talk to increase motivation and sales. Then, participants were told that one of their peers spoke up about the team's performance. They were then instructed to click on a link to hear the voice of their team member. Upon clicking the link, they heard a woman's voice ("Erica") in the female-voice conditions, or a man's voice ("Eric") in the male-voice conditions. Those in the promotive voice conditions heard the following statement:

I think that we should come up with a new and improved script in order to give us more flexibility in meeting customer needs going forward. My idea is for a new script that could include much more leeway around bundling products for our customers so that we can better meet their needs in the future. I think a new script will help all of us to be better.

Alternatively, participants in the prohibitive voice conditions heard the following:

I think that we should get rid of this ineffective script because it has restricted our flexibility in meeting customer needs in the past. My concern is that this script makes it much harder to bundle products for our customers and is harming our ability to meet their needs right now. I think getting rid of the script will fix the harm done.

After listening to the above scenario, participants evaluated their perception of Eric or Erica's status, and his or her potential for emerging as a leader, as well as several manipulation checks.

\section{Dependent and Mediator Measures}

Leader emergence. We measured leader emergence using seven items $(\alpha=.85)$ from Lanaj and Hollenbeck (2015) and adapted from Lord, Foti, and De Vader (1984), Kent and Moss (1994), and Taggar et al. (1999). Example items include whether Erica or Eric "exhibited leadership," "influenced the team," and "assumed a leadership role." Participants were asked to rate their agreement with each question on a scale of 1 (strongly disagree) to 5 (strongly agree). Higher ratings indicate that the respondent viewed Erica or Eric as emerging as a leader to a greater extent.

Status. We measured status using the same twoitem $(\alpha=.71)$ measure described in Study 1.

Manipulation checks. We conducted several manipulation checks to ensure that participants adequately distinguished between the promotive and prohibitive voice conditions, and that the conditions did not significantly vary on other, potentially confounding dimensions. All manipulation checks were assessed using a 1 (strongly disagree) to 5 (strongly agree) scale, except for the attention check. To ensure that participants were paying attention, we asked them to report whether the speaker spoke up about creating a new script or getting rid of the existing script. All participants in the promotive condition reported that the speaker spoke up about creating a new script, whereas all participants in the prohibitive condition reported that the speaker spoke up about getting rid of the existing script.

Second, we used a representative promotive voice item, and a representative prohibitive voice item, from Liang et al. (2012) to assess whether individuals in the prohibitive condition were more likely to view it as prohibitive voice compared to the promotive condition, and vice versa. We asked participants to rate their agreement with the following statements, "Eric/Erica raised a suggestion to improve the work unit" (promotive voice) and "Eric/Erica advised his/ her manager against an undesirable work practice that hampers job performance" (prohibitive voice). We further sought to ensure that both conditions were seen as being done on behalf of the collective, as this is a key attribute of both types of voice. We assessed participants' level of agreement with the statement, "Erica's/Eric's behavior emphasizes the importance of a collective mission." We next included items to ensure that our two scenarios were comparable on important content dimensions. Recent work has suggested that voice may differ in terms of size of change requested (Burris, Rockmann, 
\& Kimmons, 2017). As such, we assessed raters' perception of the scale of change being sought. Participants evaluated the question, "How large a change did Eric/Erica suggest?” Liang and colleagues (2012) also found evidence that prohibitive voice can be seen as more risky than promotive voice, and more likely to be construed as complaining. We therefore included items to test whether our conditions differed on these dimensions. To assess perceived risk, we asked participants to indicate their agreement with the statement, "It was very risky for Erica/Eric to speak up in the way that she/he did." To assess whether each type of voice was seen as complaining, we asked participants to indicate their agreement with the statement, "Erica/Eric consumes a lot of time complaining about trivial matters."

\section{RESULTS}

Descriptive statistics and correlations for all variables are listed in Table 5. The means, standard deviations, and significant differences by voice condition for each manipulation check are included in Table 6. The promotive voice condition was seen as more promotive than the prohibitive voice condition, and vice versa. There were no differences in perceived collective focus, size of change, or complaining. Like Liang et al. (2012) we found that prohibitive voice was seen as more risky than promotive voice.

\section{Hypothesis Testing}

We first conducted analyses of variance for our $2 \times$ 2 design with Tukey's honestly significant difference (HSD) contrasts between conditions. The omnibus test was significant $F(3,192)=3.30, p=.02$, and planned contrasts showed significant differences between the promotive-man condition $(M=3.95$,

TABLE 5

Study 2: Means, Standard Deviations, and Correlations

\begin{tabular}{lccccc}
\hline Variable & Mean & SD & $\mathbf{1}$ & $\mathbf{2}$ & $\mathbf{3}$ \\
\hline Voice $^{\mathrm{a}}$ & 0.51 & 0.50 & & & \\
Gender $^{\mathrm{b}}$ & 0.51 & 0.50 & 0.05 & & \\
Status & 3.73 & 0.64 & 0.07 & 0.14 & \\
Leadership & 3.92 & 0.61 & 0.09 & 0.11 & $0.50^{* *}$ \\
\hline
\end{tabular}

Notes: $n=196$

${ }^{\text {a }}$ Promotive $=1$, Prohibitive $=0$.

b $1=$ Male, $0=$ Female.

${ }^{* *} p<0.01$
TABLE 6

Study 2: Manipulation Checks

\begin{tabular}{llll}
\hline $\begin{array}{l}\text { Manipulation } \\
\text { Check }\end{array}$ & $\begin{array}{c}\text { Promotive } \\
\text { Condition }\end{array}$ & $\begin{array}{c}\text { Prohibitive } \\
\text { Condition }\end{array}$ & $\boldsymbol{F ( 1 , 1 9 4 )}$ \\
\hline $\begin{array}{l}\text { Promotive } \\
\text { Voice }\end{array}$ & $4.71(0.46)$ & $4.09(0.95)$ & $33.62^{* *}$ \\
$\begin{array}{l}\text { Prohibitive } \\
\quad \text { Voice }\end{array}$ & $2.46(1.30)$ & $4.51(0.72)$ & $182.48^{* *}$ \\
$\begin{array}{l}\text { Collective } \\
\quad \text { Focus }\end{array}$ & $4.00(0.70)$ & $3.93(0.63)$ & 0.65 \\
$\begin{array}{l}\text { Size of Change } \\
\text { Riskiness }\end{array}$ & $3.17(0.78)$ & $3.28(0.73)$ & 0.95 \\
Complaining & $2.81(1.14)$ & $3.26(1.08)$ & $8.27^{* *}$ \\
\hline
\end{tabular}

Note: $n=196$

${ }^{* *} p<0.01$

$S D=.57)$ and the promotive-woman condition $(M=$ $3.58, S D=.75, t(97)=2.82, p=.01)$, but not between the prohibitive-man $(M=3.67, S D=.69)$ and prohibitive-woman $(M=3.71, S D=.47 ; t(95)=.74$, n.s.) conditions (see Figure 3).

To test our conditional process model, we used bootstrap mediation with 1,000 random samples with replacement and percentile confidence intervals. Table 7 displays these results. The interaction between voice and gender was significantly related to status ( $\beta=.42(.18), t(193)=2.32, p=.02)$, and status was significantly related to leader emergence $(\beta=.47$ (.06), $t(194)=7.99, p<.01)$. The bootstrap analyses revealed a significant indirect effect of men's voice type on leader emergence (effect $=.13(.07), 95 \%$ CI $[.01, .27])$, and a nonsignificant indirect effect of women's voice type on leader emergence (effect $=-.06$ (.06), 95\% CI [-.19, .05]). These results further confirm the findings from the field study that promotive voice positively relates

FIGURE 3

Study 2: Status by Condition

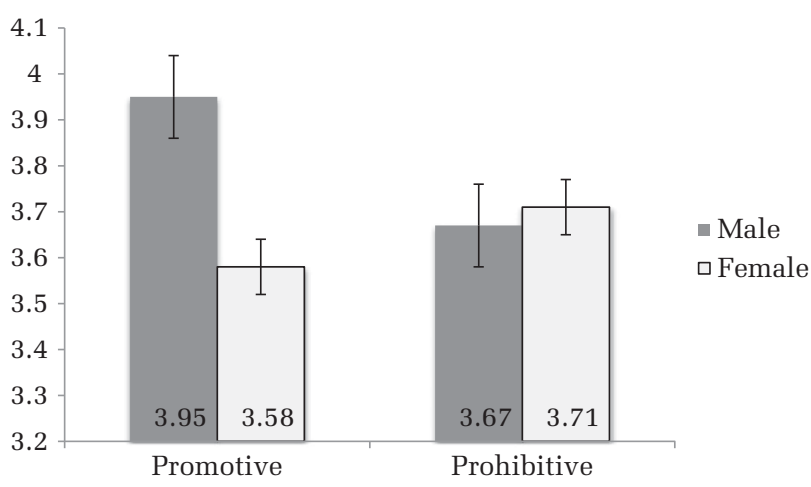


TABLE 7

Study 2: Test of Conditional Process Model

\begin{tabular}{|c|c|c|c|c|}
\hline & \multicolumn{2}{|c|}{$D V=$ Status } & \multicolumn{2}{|c|}{$D V=$ Leader Emergence } \\
\hline & $\boldsymbol{B}$ & $S E$ & $\boldsymbol{B}$ & $S E$ \\
\hline Intercept & $3.71 * *$ & 0.09 & $2.12 * *$ & 0.24 \\
\hline Voice Condition $^{\mathrm{a}}$ & -0.13 & 0.13 & 0.04 & 0.11 \\
\hline Gender Condition $^{\mathrm{b}}$ & -0.04 & 0.13 & 0.02 & 0.11 \\
\hline$F$ & 3.3 & & 16.55 & \\
\hline$R^{2}$ & 0.05 & & 0.26 & \\
\hline Adj. $R^{2}$ & 0.03 & & 0.24 & \\
\hline
\end{tabular}

\section{Conditional Indirect Effects of Voice on Emergence}

\begin{tabular}{|c|c|c|c|c|}
\hline & & 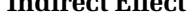 & DHECL EHEC & 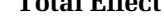 \\
\hline \multirow[t]{2}{*}{ Voice to Emergence via Status (Men) } & Effect & 0.13 & 0.09 & 0.23 \\
\hline & $95 \% \mathrm{CI}$ & {$[0.02,0.26]$} & {$[-0.11,0.30]$} & {$[0.01,0.45]$} \\
\hline Voice to Emergence via Status (Women) & Effect & -0.06 & 0.04 & -0.02 \\
\hline
\end{tabular}

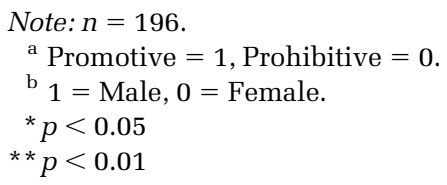

to status and subsequent leader emergence for men, but not for women.

\section{Additional Analysis}

Given that the manipulation check for riskiness of voice showed significant differences between voice conditions, we repeated the above analyses including riskiness as a covariate. There were no notable changes to the results. We also included the gender of the participant as a covariate to check whether men and women rated the targets differently. Participant gender was not a significant factor in predicting how the targets were rated, suggesting that men and women rated the targets similarly.

\section{Discussion}

Our results further support the findings from Study 1 , and suggest that promotive voice is positively related to status and subsequent leader emergence for men, but not women. Further, this analysis supported the finding from Study 1 that prohibitive voice is not positively related to status and leader emergence for men or women. In short, men benefit in terms of status and subsequent leader emergence significantly more than women do when speaking up promotively, and speaking up prohibitively does not seem to garner any status or leader emergence benefits. The results from Study 2 also suggest that the findings from Study 1 were not context specific, as a more gender-balanced sample and a more gender-balanced context still primarily allocated men the benefits associated with speaking up promotively, and the result was unaffected by whether the rater was a man or woman.

\section{GENERAL DISCUSSION}

Previous research on the individual-level outcomes of voice has focused on manager reactions to voice (Burris, 2012; Howell et al., 2015), while largely just alluding to the social consequences of speaking up (Milliken et al., 2003). In this research, we examined how different types of voice impact individuals' status and subsequent leader emergence, and the role of gender in those effects. Across two studies, we find that promotive voice is more likely to lead to status compared to prohibitive voice, and that the indirect effect of voice on leader emergence through status is affected by the speaker's gender, such that men who speak up 
promotively are more likely to gain status in their groups and emerge as leaders than are women who do so. However, engaging in prohibitive voice did not relate to leader emergence via status for men or women. These findings make several contributions to the voice literature, as well as to the leader emergence and gender literatures.

\section{Theoretical Implications}

The primary contribution of this work is that it expands the theoretical understanding of the consequences of voice by exploring these from the vantage of one's peers. This shift in perspective positions voice as a potential path to gaining status and emerging as a leader in a group. The limited research on the individual-level consequences of voice has focused almost exclusively on manager performance evaluations and endorsements of voice (Burris, 2012; Grant, 2012; Howell et al., 2015; Whiting et al., 2012; Whiting, Podsakoff, \& Pierce, 2008). While manager perceptions are critical to getting ahead in an organization, who becomes a leader is an inherently social process that also depends on peers granting influence to a person who is engaging in leader-like behaviors (Carson, Tesluk, \& Marrone, 2007; DeRue \& Ashford, 2010; Taggar et al., 1999). Failing to consider peers' perspectives of voice paints an incomplete picture of the benefits and detriments that people might consider in their voice calculus when deciding whether to speak up. We find that from the perspective of one's peers, voice can have positive effects. Specifically, engaging in voice relates to being granted increased respect from one's peers, and makes it more likely that peers will see the speaker as leader-like and be willing to defer to his or her influence.

We also bring voice research together with status and leader emergence research to provide important conditions to the long-held belief that talking in a group relates to attaining status (Kennedy et al., 2013) or emerging as a leader (Sorrentino \& Boutillier, 1975). Considering how one speaks up suggests that while voice may positively relate to higher positions in a social hierarchy, not all voice exerts the same effect. Indeed, we find that speaking up promotively, compared to prohibitively, is more strongly related to attaining status and emerging as a leader. We use EST to argue that these behaviors are seen as differing in their perceived acceptability and value, and thus correspond to differing levels of status. In addition, individuals' socially significant characteristics play an important role in this process because while voice might relate to status and emergence, it does not do so equally for men and women. Together, the EST perspectives on behaviors and characteristics suggest that the question is much more complicated than whether a person is speaking up or participating in a group; it matters how they speak up and whether they are seen as legitimate in doing so. More broadly, in light of other voice research showing that managers respond more positively to less challenging voice (Burris, 2012), an emergent trend may be that managers and peers alike respond more positively to less challenging and more future-oriented forms of voice.

In a similar vein, our work positions voice as a leadership behavior in groups, and not just something people provide to their leaders. DeRue and colleagues (2011) articulated several broad categories of leadership behaviors, including relationshiporiented behaviors, task-oriented behaviors, and change-oriented behaviors. Recent work by Lanaj and Hollenbeck (2015) explored the impact of taskoriented behaviors-including organizing and coordinating work-as a pathway to leader emergence in informal teams. They found that engagement in these behaviors was more strongly related to leader emergence for women than for men, though the extent to which the same would be true of changeoriented behaviors was unclear. As such, we do not know as much about how engaging in changeoriented behaviors relates to individuals' social positions, or how gender might influence this relationship, despite the fundamental role of change processes in groups (Cronin, Weingart, \& Todorova, 2011) and the relationship of change-oriented behaviors to a group's underlying social structures (Ilgen, Hollenbeck, Johnson, \& Jundt, 2005). We extend this literature by building theory as to why particular types of change-oriented behaviors might affect leader emergence more than others, and for whom this may be the case.

Our research also contributes to our understanding of the outcomes of promotive and prohibitive voice. Most voice research has not distinguished how people speak up, and the studies that have explored the distinction between speaking up with ideas versus problems has largely addressed the antecedents of the different types, rather than the consequences (Chamberlin et al., 2016; Liang et al., 2012). In the present research, we build and test theoretical arguments for why promotive and prohibitive voice have different social consequences. In doing so, we also contribute to EST because we further distinguish which types of assertive behaviors 
lead to more status. Prior tests of the evaluationexpectation branch of EST have suggested that assertive behavior leads to status (Fişek et al., 1991), yet few studies have tested the differences between specific types of assertive behaviors (Webster \& Raschotte, 2010). Here, we contribute by finding that promotive and prohibitive voice elicit different reactions from the speaker's peers, which in turn has implications for whether respect is granted to an individual who speaks up.

We also assess how the characteristics of the speaker, specifically gender, influence the status and leadership granting process. Research on the individual-level outcomes of voice that has addressed the speaker characteristics and reactions to voice is nascent. Only a few studies (Howell et al., 2015; Wellman, Mayer, Ong, \& DeRue, 2016; Whiting et al., 2012) have explored the effect of speaker characteristics on manager reactions to voice. Here, we extend this emerging work by drawing upon EST to explore how speakers' gender impacts the way their peers respond, and advance current theory by showing that even for a dominant group (i.e., men), not all voice is equally valued.

\section{Limitations and Future Directions}

While making the aforementioned contributions, our study has some limitations. First, the context of Study 1 was male-dominated and, although this is representative of many industries and work contexts (e.g., females make up 15\% of equity partners in legal services, $12.4 \%$ of officers in financial services, and $9 \%$ of management positions in Silicon Valley startups [Warner, 2014]), the setting and nature of the work being done is somewhat unique (Joshi \& Roh, 2009). Although we allayed these concerns to some extent in our more gender-balanced scenario experiment, future scholars could explore these relationships in other settings with different demographic compositions, such as teams with mostly women members. Howell and colleagues (2015), for instance, found that in a context where women were the dominant gender, supervisors were more likely to recognize and give credit for voice from women, but it is unclear whether the same would hold true for peers. In addition, there is evidence that the gender composition of a team influences who emerges as a leader, and that different behaviors may relate to emergence in teams comprised predominantly of women (e.g., Gershenoff \& Foti, 2003).

Second, we used self-ratings of speaking up in Study 1, and while this is consistent with other voice studies, a more objective measure of speaking up may be preferable given that there is potentially low agreement about who speaks up in a team (Burris, Detert, \& Romney, 2013). That said, our second study addresses some of these limitations by replicating our initial findings while holding the amount of voice constant and having participants evaluate the leadership potential of a person speaking up in real time. Still, future research could, and likely should, try to find more objective measures of employee voice, such as direct observation, to assess coworkers' responses to it.

Third, in this work we analyzed how someone spoke up, but did not explore the content of voice-that is, what specific ideas or problems are being voiced. One reason for this is that in Study 1 we examine teams over time, and so content is likely to vary in each voice event and with each speaker. Thus, while we provide evidence of how speaking up with promotive and prohibitive voice in repeated interactions influences social standing and leader emergence, we do not provide evidence as to whether the content of voice in discrete incidences influences how the voice is received by others. The question of voice content has been discussed in other work as a direction for future research (Burris, 2012). The limited evidence we have suggests that content matters in terms of how it influences perceptions of a speaker (see Burris et al., 2017; Wellman et al., 2016) and how speakers go about voicing different content (e.g., Detert et al., 2013). Therefore, exploring how the content of discrete voice events relates to status and leader emergence represents a fruitful direction for future work. For instance, the content of voice may affect others' perceptions of whether a speaker is self-interested (e.g., speaking up about issue of personal pay equity) or not (e.g., speaking up about issue of team's pay equity), which could affect peer perceptions of respect and influence. Indeed, research in negotiations has suggested that women may be penalized for speaking up for their selfinterests, whereas men are unlikely to be (Bowles, Babcock, \& Lai, 2007).

Fourth, we position voice as leader-like in that it is a change-oriented behavior, and change-oriented behaviors have been identified as a key category of leader behavior that relates to effectiveness across various outcomes (DeRue et al., 2011). However, voice is only one type of change-oriented behavior, and it is possible that engaging in other changeoriented behaviors, such as encouraging innovation or soliciting input from one's peers, might affect the process we describe differently. It is possible that 
enabling others to voice ideas or problems or to think outside the box could be seen as even more communally oriented and valuable to the group than speaking up oneself. Alternatively, frequently seeking information from others could be construed as less dominant or confident, and could therefore lead to lower status. This is an open question, and future research should explore how other change-oriented behaviors are seen by peers, including when they are helpful versus harmful.

A simultaneous strength and limitation of this research is that we used different measures of leader emergence in our two studies. In Study 1, we employed a rank measure because it was appropriate for the context of formal teams in which leader succession was an important concern. In Study 2, we used a rating measure because participants were only evaluating one person, and therefore a rank was not possible. While finding consistent effects when using different measures of a theoretical construct lends stronger support for hypothesized relationships, it also highlights an issue with leader emergence research more broadly. Namely, leader emergence is inconsistently defined and measured. While largely converging on the idea that emergence involves being seen by peers as engaging in leadership behaviors, scholars have defined it in various ways, including as exerting influence over other group members even without formal authority (Schneider \& Goktepe, 1983; Taggar et al., 1999), simply being seen as leader-like or standing out (Kaiser et al., 2008; Lanaj \& Hollenbeck, 2015) (which we also note is a definition that has been used for the construct of leadership itself [see Lord \& Maher, 1993; Paunonen, Lönnqvist, Verkasalo, Leikas, \& Nissinen, 2006]), and rising to a position of leadership (Brunell, Gentry, Campbell, Hoffman, Kuhnert, \& DeMarree, 2008). Similarly, the construct has been operationalized using rank measures (Smith \& Foti, 1998; Zaccaro et al., 1991), various scale ratings (e.g., Brunell et al., 2008; Kent \& Moss, 1994), network measures (e.g., Zhang, Waldman, \& Wang, 2012), forced rankings (Paunonen et al., 2006), and various combinations of the above. Moreover, in some cases, the items used to capture the theoretical concept appear to conflate it with other constructs, such as effectiveness or contribution to the team. The variation in how leader emergence is defined and measured raises questions as to whether all of these approaches are measuring the same dimensions of emergence, and whether some measures may be better suited for answering particular questions than others. Here, our results using the two measures we deemed appropriate for the specific contexts of Studies 1 and 2 provided consistent results regarding the relationships among our focal variables. That being said, future work in leader emergence may do well to lay a foundational definition of the theoretical concept and, as we have preliminarily done here, suggest consistent ways of measuring it.

Last, we assessed leader emergence in teams that have formal leaders; however, we did not assess the impact of the formal leader on the leader emergence process. This is a fruitful area for future research that few have explored (see Zhang et al., 2012 for an exception). Theoretically, formal leaders could affect the relationship between voice and leader emergence by influencing team members' perceptions of safety and futility, or other known antecedents to speaking up (Detert \& Burris, 2007; Morrison, 2014). This in turn could change the overall baseline level of voice in a team, and perhaps dilute the extent to which speaking up accrues status because if everyone speaks up then it may be that no one adds more value than anyone else. Alternatively, a boss that actively suppresses voice could create a situation in which peers view someone that speaks up as a hero, such that that person accrues tremendous status for speaking truth to power. We encourage scholars to pursue this interesting line of research in future studies.

\section{Practical Implications}

Beyond the theoretical contributions, our results are practically meaningful. A frequently asked question across disciplines is "who gets ahead and why?" Our paper addresses this question and offers a behavioral suggestion for how employees might gain respect and influence within organizations. Our results suggest that voice influences one's social position in a team and that, to get ahead, speaking up in a way that focuses on ideas that move the group toward an ideal state may be particularly beneficial.

That said, our results also give rise to concern, as the benefits of speaking up are not equal for everyone. Indeed, many notable public cases have called attention to the inconsistent evaluations of men and women for engaging in behaviors that lead to leadership positions. For example, the case of Ellen Pao, a former investing partner at a well-known Silicon Valley venture capital firm who was passed up for promotion and subsequently sued her former employer for gender discrimination, highlighted the challenging position of women who are asked to be more change-oriented, to speak up, or "lean in," yet 
do not receive equal evaluation for doing so (Streitfeld, 2015). Our work highlights a subtle way through which women may be discriminated against in the promotion process within organizations. Although women may spend time speaking up, they do not appear to receive the same benefit as men. In addition, although we did not find a backlash effect for this behavior, the time women spend performing change-oriented behaviors without receiving credit can reasonably be expected to fetter their promotion and development in the long term. We recommend that managers explore methods to countervail this tendency. Two potential avenues for ensuring equity in the status-conferral process as it relates to voice may be in-the-moment documentation or concerted recognition and amplification of voice, where others repeat the idea and ensure that credit is given to the woman speaking up (Eilperin, 2016). This action will help legitimize women's voices because others will sense that it is more valid, which should result in more positive evaluations of the speakers themselves (Berger, Ridgeway, Fişek, \& Norman, 1998).

\section{CONCLUSION}

Our work extends theory on the outcomes of voice by articulating a pathway through which voice impacts individuals' status within a group and their subsequent tendency to emerge as a leader. It also highlights that not all types of voice are equal in this process, and that the strength of the relationships between voice, status, and leader emergence is different for men versus women. In doing this, we link and extend theory across several streams of research, while also raising an important concern. Indeed, our results suggest that although voice can be beneficial to one's status and leader emergence, the benefits associated with speaking are more strongly felt for men. Thus, there is work yet to be done to better understand how men and women can come to be evaluated fairly when speaking up with their ideas for change.

\section{REFERENCES}

Anderson, C., \& Kilduff, G. J. 2009a. The pursuit of status in social groups. Current Directions in Psychological Science, 18: 295-298.

Anderson, C., \& Kilduff, G. J. 2009b. Why do dominant personalities attain influence in face-to-face groups? The competence-signaling effects of trait dominance. Journal of Personality and Social Psychology, 96: 491-503.

Anderson, C., Kraus, M. W., Galinsky, A. D., \& Keltner, D. 2012. The local-ladder effect: Social status and subjective well-being. Psychological Science, 23: 764-771.

Armstrong-Stassen, M. 1998. The effect of gender and organizational level on how survivors appraise and cope with organizational downsizing. The Journal of Applied Behavioral Science, 34: 125-142.

Ashford, S. J. 1988. Individual strategies for coping with stress during organizational transitions. The Journal of Applied Behavioral Science, 24: 19-36.

Ayman, R., \& Korabik, K. 2010. Leadership: Why gender and culture matter. The American Psychologist, 65: 157-170.

Barsade, S. G. 2002. The ripple effect: Emotional contagion and its influence on group behavior. Administrative Science Quarterly, 47: 644-675.

Bass, B. M. 1954. The leaderless group discussion. Psychological Bulletin, 51: 465-492.

Bass, B. M. 1981. Stogdill's handbook of leadership. New York, NY: Free Press.

Berger, J., Cohen, B. P., \& Zelditch, M., Jr.. 1972. Status characteristics and social interaction. American Sociological Review, 37: 241-255.

Berger, J., Conner, T. L., \& Fişek, M. H. 1974. Expectation states theory: A theoretical research program. Cambridge, MA: Winthrop.

Berger, J., Ridgeway, C. L., Fişek, M. H., \& Norman, R. Z. 1998. The legitimation and delegitimation of power and prestige orders. American Sociological Review, 63: 379-405.

Blader, S. L., \& Chen, Y. R. 2014. What's in a name? Status, power, and other forms of social hierarchy. In J. T. Cheng, J. L. Tracy, \& C. Anderson (Eds.), The psychology of social status: 71-95. New York, NY: Springer.

Bowles, H. R., Babcock, L., \& Lai, L. 2007. Social incentives for gender differences in the propensity to initiate negotiations: Sometimes it does hurt to ask. Organizational Behavior and Human Decision Processes, 103: 84-103.

Brunell, A. B., Gentry, W. A., Campbell, W. K., Hoffman, B. J., Kuhnert, K. W., \& DeMarree, K. G. 2008. Leader emergence: The case of the narcissistic leader. Personality and Social Psychology Bulletin, 34: 1663-1676.

Burke, M. J., \& Dunlap, W. P. 2002. Estimating interrater agreement with the average deviation index: A user's guide. Organizational Research Methods, 5: 159-172.

Burris, E. R. 2012. The risks and rewards of speaking up: Managerial responses to employee voice. Academy of Management Journal, 55: 851-875.

Burris, E. R., Detert, J. R., \& Romney, A. C. 2013. Speaking up vs. being heard: The disagreement around and 
outcomes of employee voice. Organization Science, 24: $22-38$.

Burris, E. R., Rockmann, K., \& Kimmons, Y. S. 2017. The value of voice (to managers): Employee identification and the content of voice. Academy of Management Journal, 60: 2099-2125.

Carlson, K. D., \& Wu, J. 2011. The illusion of statistical control: Control variables practice in management research. Organizational Research Methods, 15: 413-435.

Carson, J. B., Tesluk, P. E., \& Marrone, J. A. 2007. Shared leadership in teams: An investigation of antecedent conditions and performance. Academy of Management Journal, 50: 1217-1234.

Cartwright, S., \& Cooper, C. L. 1993. The role of culture compatibility in successful organizational marriage. The Academy of Management Executive, 7: 57-70.

Chamberlin, M., Newton, D. W., \& Lepine, J. A. 2016. A meta-analysis of voice and its promotive and prohibitive forms: Identification of key associations, distinctions, and future research directions. Personnel Psychology, 70: 11-71.

Cialdini, R. B., Borden, R. J., Thorne, A., Walker, M. R., Freeman, S., \& Sloan, L. R. 1976. Basking in reflected glory: Three (football) field studies. Journal of Personality and Social Psychology, 34: 366-375.

Correll, S. J., \& Ridgeway, C. L. 2003. Expectation states theory. In J. Delamater (Ed.), Handbook of social psychology: 29-51. New York, NY: Kluwer Academic Press.

Crant, J. M. 1995. The Proactive Personality Scale and objective job performance among real estate agents. The Journal of Applied Psychology, 80: 532537.

Cronin, M. A., Weingart, L. R., \& Todorova, G. 2011. Dynamics in groups: Are we there yet? The Academy of Management Annals, 5: 571-612.

Crowe, E., \& Higgins, E. T. 1997. Regulatory focus and strategic inclinations: Promotion and prevention in decision-making. Organizational Behavior and Human Decision Processes, 69: 117-132.

de Gelder, B., Snyder, J., Greve, D., Gerard, G., \& Hadjikhani, N. 2004. Fear fosters flight: a mechanism for fear contagion when perceiving emotion expressed by a whole body. Proceedings of the National Academy of Sciences of the United States of America, 101: 16701-16706.

DeRue, D. S., \& Ashford, S. J. 2010. Who will lead and who will follow? A social process of leadership identity construction in organizations. Academy of Management Review, 35: 627-647.

DeRue, D. S., Nahrgang, J. D., Wellman, N., \& Humphrey, S. E. 2011. Trait and behavioral theories of leadership:
An integration and meta-analytic test of their relative validity. Personnel Psychology, 64: 7-52.

Detert, J. R., \& Burris, E. R. 2007. Leadership behavior and employee voice: Is the door really open? Academy of Management Journal, 50: 869-884.

Detert, J. R., Burris, E. R., Harrison, D. A., \& Martin, S. R. 2013. Voice flows to and around leaders understanding when units are helped or hurt by employee voice. Administrative Science Quarterly, 58: 624-668.

Detert, J. R., \& Edmondson, A. C. 2011. Implicit voice theories: Taken-for-granted rules of self-censorship at work. Academy of Management Journal, 54: 461488.

Eagly, A. H., \& Karau, S. J. 1991. Gender and the emergence of leaders: A meta-analysis. Journal of Personality and Social Psychology, 60: 685-710.

Eagly, A. H., \& Wood, W. 1982. Inferred sex differences in status as a determinant of gender stereotypes about social influence. Journal of Personality and Social Psychology, 43: 915-928.

Edmondson, A. C. 1999. Psychological safety and learning behavior in work teams. Administrative Science Quarterly, 44: 350-383.

Edmondson, A. C. 2003. Speaking up in the operating room: How team leaders promote learning in interdisciplinary action teams. Journal of Management Studies, 40: 1419-1452.

Edwards, J. R., \& Lambert, L. S. 2007. Methods for integrating moderation and mediation: A general analytical framework using moderated path analysis. Psychological Methods, 12: 1-22.

Eilperin, J. 2016. White House women want to be in the room where it happens. The Washington Post, September 13, Retrieved from https://www. washingtonpost.com/news/powerpost/wp/2016/09/ 13/white-house-women-are-now-in-the-room-whereit-happens.

Ellemers, N., De Gilder, D., \& Haslam, S. A. 2004. Motivating individuals and groups at work: A social identity perspective on leadership and group performance. Academy of Management Review, 29: 459-478.

Ensari, N., Riggio, R. E., Christian, J., \& Carslaw, G. 2011. Who emerges as a leader? Meta-analyses of individual differences as predictors of leadership emergence. Personality and Individual Differences, 51: 532536.

Fişek, M. H., Berger, J., \& Norman, R. Z. 1991. Participation in heterogeneous and homogeneous groups: A theoretical integration. American Journal of Sociology, 97: 114-142.

Fiske, S. T. 1998. Stereotyping, prejudice, and discrimination at the seam between the centuries: Evolution, 
culture, mind, and brain. In D. T. Gilbert, S. T. Fiske, \& G. Lindzey (Eds.), Handbook of social psychology, vol. 2: 357-411. New York, NY: McGraw-Hill.

Fiske, S. T., \& Berdahl, J. 2007. Social power. In A. W. Kruglansk \& E. T. Higgins (Eds.), Social psychology: Handbook of basic principles: 678-692. New York, NY: Guilford.

Fiske, S. T., Cuddy, A. J., Glick, P., \& Xu, J. 2002. A model of (often mixed) stereotype content: competence and warmth respectively follow from perceived status and competition. Journal of Personality and Social Psychology, 82: 878-902.

Foti, R. J., \& Hauenstein, N. 2007. Pattern and variable approaches in leadership emergence and effectiveness. The Journal of Applied Psychology, 92: 347-355.

Gershenoff, A. B., \& Foti, R. J. 2003. Leader emergence and gender roles in all-female groups: A contextual examination. Small Group Research, 34: 170-196.

Gosling, S. D., Rentfrow, P. J., \& Swann, W. B. 2003. A very brief measure of the Big-Five personality domains. Journal of Research in Personality, 37: 504-528.

Graffin, S. D., Wade, J. B., Porac, J. F., \& McNamee, R. C. 2008. The impact of CEO status diffusion on the economic outcomes of other senior managers. Organization Science, 19: 457-474.

Grant, A. M. 2012. Leading with meaning: Beneficiary contact, prosocial impact, and the performance effects of transformational leadership. Academy of Management Journal, 55: 458-476.

Hall, J. A. 1979. Gender, gender roles, and nonverbal communication skills. In R. Rosenthal (Ed.), Skill in nonverbal communication: Individual differences: 32-67. Cambridge, MA: Oelgeschlager, Gunn \& Hain.

Hardy, C. L., \& Van Vugt, M. 2006. Nice guys finish first: The competitive altruism hypothesis. Personality and Social Psychology Bulletin, 32: 1402-1413.

Howell, T. M., Harrison, D. A., Burris, E. R., \& Detert, J. R. 2015. Who gets credit for input? Demographic and structural status cues in voice recognition. The Journal of Applied Psychology, 100: 1765-1784.

Hu, L., \& Bentler, P. M. 1999. Cutoff criteria for fit indexes in covariance structure analysis: Conventional criteria versus new alternatives. Structural Equation Modeling, 6: 1-55.

Ilgen, D. R., Hollenbeck, J. R., Johnson, M., \& Jundt, D. 2005. Teams in organizations: From input-process-output models to IMOI models. Annual Review of Psychology, 56: 517-543.

Joshi, A., \& Roh, H. 2009. The role of context in work team diversity research: A meta-analytic review. Academy of Management Journal, 52: 599-627.
Kaiser, R. B., Hogan, R., \& Craig, S. B. 2008. Leadership and the fate of organizations. The American Psychologist, 63: $96-110$.

Kark, R., \& Van Dijk, D. 2007. Motivation to lead, motivation to follow: The role of the self-regulatory focus in leadership processes. Academy of Management Review, 32: 500-528.

Kennedy, J. A., Anderson, C., \& Moore, D. A. 2013. When overconfidence is revealed to others: Testing the status-enhancement theory of overconfidence. Organizational Behavior and Human Decision Processes, 122: 266-279.

Kent, R. L., \& Moss, S. E. 1994. Effects of sex and gender role on leader emergence. Academy of Management Journal, 37: 1335-1346.

Kilduff, G. J., \& Galinsky, A. D. 2013. From the ephemeral to the enduring: How approach-oriented mindsets lead to greater status. Journal of Personality and Social Psychology, 105: 816-831.

Kish-Gephart, J. J., Detert, J. R., Treviño, L. K., \& Edmondson, A. C. 2009. Silenced by fear: The nature, sources, and consequences of fear at work. Research in Organizational Behavior, 29: 163-193.

Lanaj, K., Chang, C. H., \& Johnson, R. E. 2012. Regulatory focus and work-related outcomes: A review and metaanalysis. Psychological Bulletin, 138: 998-1034.

Lanaj, K., \& Hollenbeck, J. R. 2015. Leadership overemergence in self-managing teams: The role of gender and countervailing biases. Academy of Management Journal, 58: 1476-1494.

Liang, J., Farh, C. I., \& Farh, J. L. 2012. Psychological antecedents of promotive and prohibitive voice: A twowave examination. Academy of Management Journal, 55: 71-92.

Lin, S. J., \& Johnson, R. E. 2015. A suggestion to improve a day keeps your depletion away: Examining promotive and prohibitive voice behaviors within a regulatory focus and ego depletion framework. The Journal of Applied Psychology, 100: 1381-1397.

Lord, R. G., Foti, R. J., \& De Vader, C. L. 1984. A test of leadership categorization theory: Internal structure, information processing, and leadership perceptions. Organizational Behavior and Human Performance, 34: 343-378.

Lord, R. G., \& Maher, K. J. 1993. Leadership and information processing: Linking perceptions and performance. New York, NY: Routledge.

Lovaglia, M. J., \& Houser, J. A. 1996. Emotional reactions and status in groups. American Sociological Review, 61: 867-883.

Magee, J. C., \& Galinsky, A. D. 2008. Social hierarchy: The self-reinforcing nature of power and status. The Academy of Management Annals, 2: 351-398. 
Maynes, T. D., \& Podsakoff, P. M. 2014. Speaking more broadly: An examination of the nature, antecedents, and consequences of an expanded set of employee voice behaviors. The Journal of Applied Psychology, 99: 87-112.

McClean, E. J., Burris, E. R., \& Detert, J. R. 2013. When does voice lead to exit? It depends on leadership. Academy of Management Journal, 56: 525-548.

Milliken, F. J., Morrison, E. W., \& Hewlin, P. F. 2003. An exploratory study of employee silence: Issues that employees don't communicate upward and why. Journal of Management Studies, 40: 1453-1476.

Morrison, E. W. 2014. Employee voice and silence. Annual Review of Psychology and Organizational Behavior, 1: 173-197.

Mullen, B., Salas, E., \& Driskell, J. E. 1989. Salience, motivation, and artifact as contributions to the relation between participation rate and leadership. Journal of Experimental Social Psychology, 25: 545-559.

Paunonen, S. V., Lönnqvist, J. E., Verkasalo, M., Leikas, S., \& Nissinen, V. 2006. Narcissism and emergent leadership in military cadets. The Leadership Quarterly, 17: 475-486.

Pettit, N. C., Yong, K., \& Spataro, S. E. 2010. Holding your place: Reactions to the prospect of status gains and losses. Journal of Experimental Social Psychology, 46: 396-401.

Ridgeway, C. L. 2001. Gender, status, and leadership. The Journal of Social Issues, 57: 637-655.

Ridgeway, C. L., Backor, K., Li, Y. E., Tinkler, J. E., \& Erickson, K. G. 2009. How easily does a social difference become a status distinction? Gender matters. American Sociological Review, 74: 44-62.

Riggio, R. E. 1986. Assessment of basic social skills. Journal of Personality and Social Psychology, 51: 649-660.

Schneider, C. E., \& Goktepe, J. R. 1983. Issues in emergent leadership: The contingency model of leadership, leader sex, leader behavior. In H. H. Blumberg, A. P. Hare, V. Kent, \& M. F. Davies (Eds.), Small groups and social interaction, vol. 1: 413-421. Chichester, U.K.: Wiley.

Smith, J. A., \& Foti, R. J. 1998. A pattern approach to the study of leader emergence. The Leadership Quarterly, 9: 147-160.

Sorrentino, R. M., \& Boutillier, R. G. 1975. The effect of quantity and quality of verbal interaction on ratings of leadership ability. Journal of Experimental Social Psychology, 11: 403-411.

Sorrentino, R. M., \& Field, N. 1986. Emergent leadership over time: The functional value of positive motivation. Journal of Personality and Social Psychology, 50: 1091-1099.
Streitfeld, D. 2015. In Ellen Pao's Suit vs. Kleiner Perkins, world of venture capital is under microscope. The New York Times, March 5. Retrieved from https:// www.nytimes.com/2015/03/06/technology/in-ellenpaos-suit-vs-kleiner-perkins-world-of-venture-capitalis-under-microscope.html.

Taggar, S., Hackew, R., \& Saha, S. 1999. Leadership emergence in autonomous work teams: Antecedents and outcomes. Personnel Psychology, 52: 899-926.

Tajfel, H., \& Turner, J. C. 1979. An integrative theory of intergroup conflict. In W. G. Austin \& S. Worchel (Eds.), The social psychology of intergroup relations: 33-47. Monterey, CA: Brooks Cole.

Tepper, B. J., Duffy, M. K., Hoobler, J., \& Ensley, M. D. 2004. Moderators of the relationships between coworkers' organizational citizenship behavior and fellow employees' attitudes. The Journal of Applied Psychology, 89: 455-465.

Tiedens, L. Z. 2001. Anger and advancement versus sadness and subjugation: The effect of negative emotion expressions on social status conferral. Journal of Personality and Social Psychology, 80: 86-94.

Tonidandel, S., \& LeBreton, J. M. 2011. Relative importance analysis: A useful supplement to regression analysis. Journal of Business and Psychology, 26: 1-9.

U.S. Department of Labor, Bureau of Labor Statistics (2014). Current Population Survey. Retrieved from https://www.bls.gov/cps/

Warner, J. 2014. The women's leadership gap: Women's leadership by the numbers. The Center for American Progress, March 7. Retrieved from https://cdn. americanprogress.org/wp-content/uploads/2014/03/ WomenLeadership.pdf.

Webster, M., \& Raschotte, L. S. 2010. Behavior, expectations, status. Social Forces, 88: 1021-1049.

Wellman, N., Mayer, D. M., Ong, M., \& DeRue, D. S. 2016. When are do-gooders treated badly? Legitimate power, role expectations, and reactions to moral objection in organizations. The Journal of Applied Psychology, 101: 793-814.

Whiting, S. W., Maynes, T. D., Podsakoff, N. P., \& Podsakoff, P. M. 2012. Effects of message, source, and context on evaluations of employee voice behavior. The Journal of Applied Psychology, 97: 159-182.

Whiting, S. W., Podsakoff, P. M., \& Pierce, J. R. 2008. Effects of task performance, helping, voice, and organizational loyalty on performance appraisal ratings. The Journal of Applied Psychology, 93: 125-139.

Zaccaro, S. J., Foti, R. J., \& Kenny, D. A. 1991. Selfmonitoring and trait-based variance in leadership: An investigation of leader flexibility across multiple 
group situations. The Journal of Applied Psychology, 76: 308-315.

Zhang, Z., Waldman, D. A., \& Wang, Z. 2012. A multilevel investigation of leader-member exchange, informal leader emergence, and individual and team performance. Personnel Psychology, 65: 49-78.

Zhao, X., Lynch, J. G., \& Chen, Q. 2010. Reconsidering Baron and Kenny: Myths and truths about mediation analysis. The Journal of Consumer Research, 37: 197-206.

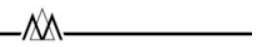

Elizabeth J. McClean (emcclean@email.arizona.edu) is an assistant professor of management and organizations at the Eller College of Management at the University of Arizona. She received her PhD from the Industrial and Labor Relations School at Cornell University. Her research focuses on voice, leadership, and strategic human resource management.
Sean R. Martin (MartinS@darden.virginia.edu) is an associate professor of business administration at the Darden School of Business at the University of Virginia. He received his $\mathrm{PhD}$ in management from the Johnson School of Management at Cornell University. His research interests include leadership, values and social class.

Kyle J. Emich (kemich@udel.edu) is an assistant professor at the Alfred Lerner College of Business and Economics at the University of Delaware. He received his $\mathrm{PhD}$ from the Industrial and Labor Relations School at Cornell University. His research explores the role of individual traits, perceptions, and emotions in groups.

Col. Todd Woodruff (todd.woodruff@usma.edu) is an associate professor and director of the Eisenhower Leader Development Program at the United States Military Academy, WestPoint. He received his PhD from the Kenan-Flagler Business School at the University of North Carolina. His research addresses organizational culture, motivation, and citizenship behavior. 
Copyright of Academy of Management Journal is the property of Academy of Management and its content may not be copied or emailed to multiple sites or posted to a listserv without the copyright holder's express written permission. However, users may print, download, or email articles for individual use. 